\title{
Meta
}

Journal des traducteurs

Translators' Journal

\section{Watson Kirkconnell and the "Undoing of Babel": a Little-Known Case in Canadian Translation History}

\section{Judith Woodsworth}

Volume 45, numéro 1, avril 2000

La traduction littéraire au Canada

Literary Translation in Canada

URI : https://id.erudit.org/iderudit/004618ar

DOI : https://doi.org/10.7202/004618ar

Aller au sommaire du numéro

Éditeur(s)

Les Presses de l'Université de Montréal

ISSN

0026-0452 (imprimé)

1492-1421 (numérique)

Découvrir la revue

Citer cet article

Woodsworth, J. (2000). Watson Kirkconnell and the "Undoing of Babel": a Little-Known Case in Canadian Translation History. Meta, 45(1), 13-28. https://doi.org/10.7202/004618ar
Résumé de l'article

Watson Kirkconnell (1895-1977) était un érudit, un membre de l'administration universitaire et un extraordinaire traducteur de poésie écrite dans des dizaines de langues. Pour- tant, encore aujourd'hui, il est presque inconnu dans le milieu canadien de la traduction.Cet article présente la vie, l'œuvre et la pensée de Kirkconnell puis rend compte de cet oubli dans le contexte du paysage linguistique du Canada. 


\title{
Watson Kirkconnell and the "Undoing of Babel": a Little-Known Case in Canadian Translation History
}

\author{
JUDITH WOODSWORTH \\ Mount Saint Vincent University
}

\begin{abstract}
RÉSUMÉ
Watson Kirkconnell (1895-1977) était un érudit, un membre de l'administration universitaire et un extraordinaire traducteur de poésie écrite dans des dizaines de langues. Pourtant, encore aujourd'hui, il est presque inconnu dans le milieu canadien de la traduction. Cet article présente la vie, l'œuvre et la pensée de Kirkconnell puis rend compte de cet oubli dans le contexte du paysage linguistique du Canada.
\end{abstract}

\begin{abstract}
Watson Kirkconnell (1895-1977) was a scholar, university administrator and prodigious translator of verse from dozens of languages. Yet today he is virtually unknown in the translation community in this country. This article examines the life, work and thought of Kirkconnell, and situates the neglect into which he has fallen in the context of the linguistic landscape of Canada.
\end{abstract}

\section{MOTS-CLÉS/KEYWORDS}

Watson Kirkconnell, literary translation, Canada, European languages, poetry

Brighton, 1993. At the World Congress of the Fédération Internationale des Traducteurs, in a workshop on "Languages of Limited Diffusion," two of the presenters refer to the work of a Canadian translator called Watson Kirkconnell. Zsuzsanna Ujszászi (1993) speaks about Kirkconnell's translations of Hungarian poetry. Through translation, she points out, the poetry of a less important European language was made accessible to the English-speaking world. Rokszana Zorivchak describes Kirkconnell's role in translating the great Ukrainian poet Taras Shevckenko, labelling Kirkconnell "a scholar and a poet, and one of Canada's most distinguished linguists" (Zorivchak 1993: 574). I am surprised to hear international scholars speak so highly of a Canadian translator about whom I know nothing. Just a reflection of my own ignorance perhaps, but I check with Canadian colleagues present at the conference. For them, as for me, Watson Kirkconnell is "un parfait inconnu".

My interest was sparked on that occasion, and I have since had occasion to investigate this prolific scholar and translator of more than 4000 pages of verse from dozens of languages. His career was an extremely full and varied one, with translation merely one of its dimensions. A man of phenomenal achievements, credited with the "undoing of Babel," Watson Kirkconnell (1895-1977) is cited briefly in the Canadian Encyclopedia under the rubric "Ethnic Literature" but he is virtually unknown in translation circles.

This article attempts to shed light on the life, times and accomplishments of Watson Kirkconnell. After a biographical overview, it will examine the nature of his 
work as a translator, and some of his thoughts on the art of translation. The paper also seeks to elucidate the relative obscurity into which this translator has fallen, situating his work on the myriad ethnic literatures of this country against the backdrop of official bilingualism, the so-called "vertical mosaic," and the political debates in which he was engaged.

\section{Life of Watson Kirkconnell}

Watson Kirkconnell was born in Port Hope, Ontario in 1895, the son of the headmaster of the local high school. He was a frail child and therefore began school late, but he was studious and excelled in a wide range of subjects in high school. Although inherently a polymath-interested in the sciences, literature, anthropology, and more-he was always fond of languages. As he says in his memoirs, A Slice of Canada, "The labours of my lifetime have been more in the field of language study than in any other" (Kirkconnell 1967: 34). By the time he finished high school, he had studied Latin, French, German and Greek and had been exposed to works on comparative philology. These pursuits continued at Queen's University, where he studied classics, "in love with language for its own sake" (Kirkconnell 1967: 35). By 1916, he had obtained a Master's degree.

Kirkconnell's academic interests were then interrupted by the War. He was not in action because he was deemed to be medically unfit. He spent three years as a Captain with the Department of Internment Operations. He travelled to Germany at the end of the war to repatriate German prisoners. He arrived home in 1919, after an illness, too late to pursue the Ph.D. programme in Education at Harvard he had planned for.

He took voice lessons but was prevented from pursuing this course of study because of illness and chronic laryngitis. Though forced to abandon the idea of a career in music, he participated throughout his life in church choirs, light opera, and even frivolous musical enterprises.

Kirkconnell then began to think of a career in journalism and took correspondence courses from a journalism school in London, England. He went on a scholarship to Oxford, where instead of reading the "Greats" as one would have expected because of his background in classics, he studied Economics, hoping that it would improve his chances of a career in journalism. He wrote a thesis on "International Aspects of Unemployment," which was published by George Allen \& Unwin in 1923, but he was not actually granted his degree.

In 1922, he was invited to fill a vacancy in the English Department at Wesley College, which later became United College and is now the University of Winnipeg. He remained there for eighteen years; for the first eleven years, he taught English and for the remainder he served as Head of the Department of Classics. It was in Winnipeg that he "began to pick up the lost threads of [his] old philological dream" (Kirkconnell 1967: 36). In teaching English he became acquainted with Old English, Middle English and the history of the English language, and from there went on to become familiar with Gothic, Sanskrit and Indo-European comparative grammar. From 1925 to 1930, he expanded his library to include dictionaries of all the languages of Europe, as well as a few more exotic ones such as Hebrew, Egyptian, Persian and Chinese. He collected grammars and phonograph records and also delved into the 
study of linguistics. "Captivated by the interrelatedness of language patterns and the reappearance in many literatures of certain basic themes" (Perkin 1986: 15), Kirkconnell laid the foundations for the monumental projects he was about to undertake.

In his autobiography, Kirkconnell recounts this preparation as an explanation for his familiarity with so wide a range of languages. His abilities do not stem from any "pedagogical gimmick" or "freak psychological gift," he says, but rather from "acute visual memory, intense powers of concentration, and intellectual enthusiasms that never seem to abate" (Kirkconnell 1967: 40).

In 1924, Kirkconnell married Isabel Peel. In 1925, she died while giving birth to twin boys. As an antidote to his grief at his wife's untimely death, Kirkconnell began to translate elegiac poems into English. The result was European Elegies, a collection of one hundred poems from fifty languages, which will be examined more fully in the following section. After the publication of European Elegies in 1928, Kirkconnell went on to produce a body of work that is prodigious in both volume and scope, including original verse, translations, literary criticism and other writings.

He remarried in 1930 and resumed family life. He was involved in a wide range of activities in academia and beyond. He maintained an active interest in political matters, publishing a number of works of a political nature, and in affairs of the Baptist Church.

In 1940, Kirkconnell took up the position of Head of the Department of English at McMaster University, at the time a denominational institution affiliated with the Baptist Convention of Ontario and Quebec. During his years at McMaster, 1940 to 1948, Kirkconnell was deeply involved in politics. He also continued his religious involvement and worked toward the creation of a pan-Canadian Baptist Federation (1944). He was instrumental in the founding, in 1943, of the Humanities Research Council of Canada, the forerunner of the Canadian Federation for the Humanities, which has recently evolved into the Social Sciences and Humanities Federation of Canada. During the Hamilton years, Kirkconnell demonstrated his administrative and diplomatic abilities in addition to those of scholar and writer. This led to his appointment in 1948 as the first lay President of Acadia University in Wolfville, Nova Scotia, which like McMaster was a Baptist institution.

When Kirkconnell arrived at Acadia, he faced some major challenges: enrolment had swelled with the return of servicemen, but the funding provided by the church was not sufficient. Kirkconnell worked with fellow university presidents to obtain funding from the provincial government. In addition to administrative and teaching responsibilities, he continued to engage in scholarly activities. He was admired for the discipline with which he was able to fulfil his duties and also maintain a "herculean publishing schedule" (Perkin 1986: 36). Each year, he took a one-month vacation in Ontario, where he would complete the manuscript of a book and continue working on several other projects.

He retired as president of Acadia in 1964, but remained closely associated with the university. He taught English courses for two more years, and then continued with his scholarly and other writing. He continued to live in Wolfville until his death in 1977. In 1979, the Watson Kirkconnell Room was opened at the Vaughan Library of Acadia University to house his decorations and medals, books, personal files and manuscripts. 


\section{European Elegies}

In the preface to European Elegies, Kirkconnell makes the point that his translations are "unaided renderings from the original languages" (Kirkconnell 1928: 9). Since this was a personal exercise, he did not seek the advice or assistance of experts in the various foreign languages he tackled, as he was to do later in his career.

The languages from which the poems are translated number fifty all told, although in the proposal to his publishers he originally mentions forty. Some of these are earlier forms of the same modern European language: Old High German, Middle High German, Old Icelandic, Old Spanish, Old Welsh, for example. Some of the languages listed could be considered dialects, such as Plattdeutsch and Erse (a dialect of Gaelic).

At the time of the project, Kirkconnell's bookcase housed over eighty dictionaries in sixty languages (Kirkconnell 1967: 37). These dictionaries, however, were not entirely helpful since many were not even intended for English users. The best dictionary of Icelandic, for example, gave its definitions in Danish and his only dictionary of Latvian was Latvian-Russian (Kirkconnell 1967: 57).

In compiling the anthology, Kirkconnell's choices were in the first instance personal ones. He translated the poems to which he had the strongest emotional reaction during his moments of mourning. The anthology was further limited by the availability of material. In Winnipeg, at that time, libraries offered works in no more than a half dozen of the major languages of Europe. He therefore made use of his private collection, further restricted by his “young scholar's purse” (Kirkconnell 1928: 9). Once chosen, the poems were ordered not chronologically or alphabetically, but rather thematically, in accordance with a "vague general history of emotional experience," moving from the autumn season through winter, summer, spring and back to autumn.

Kirkconnell's method, as he explains in his Preface, was "comparatively simple" (Kirkconnell 1928: 9):

First choosing some poem that had moved me in the original, I keep that original before me, mumbling it aloud and brooding over it until I have saturated my mind with its emotion. Then I endeavour to reproduce its form and spirit in English as accurately as possible, reserving only the conviction that a literal translation is inherently criminal and that any verse rendering which sacrifices beauty to philology is a blasphemous offence in its very existence. (Kirkconnell 1928: 9-10)

Here, Kirkconnell raises the age-old polarity of form versus content, and free versus literal translation. He goes on to highlight the difficulties to which verse translation gives rise. They are formal in nature-metre, rhyme, alliteration - the very elements that define the musicality of the verse. They are so inextricably tied to the original language, in fact, that they nearly defy translation. When he had "reincarnated poems in English verse, life beat so feebly in their veins that their only hope of survival lay in a transfusion of [his] own blood" (Kirkconnell 1928: 10). This kind of transfusion resulted in liberties, omissions, and changes to words, phrases and even titles.

These comments about a translator's challenges are relatively commonplace in a translator's preface, particularly when the translator is grappling with the nearly impossible task of translating poetry. What is unique in Watson Kirkconnell's preface is his view of translation as a way of reaching humanity in general. Before undertaking 
his translation project, he had believed in an "academic" way in the "common humanity of mankind". Through the poetry of fifty literatures, he came to understand the "common perception of the sacredness of grief and the beauty of life even in its tragedy" (Kirkconnell 1928: 12). Translation can thus contribute to the bringing together of modern nations otherwise "isolated and estranged by their very loyalties to speech, kin, and faith" (Kirkconnell, 1928: 12).

The "preface" of European Elegies is followed by an "introduction" in which Kirkconnell analyses the art of translation and, in particular, the nature of verse translation. The essay is relatively sophisticated given the times and the stage of Kirkconnell's career, and was perceived as such in subsequent appraisals of the European Elegies.

Kirkconnell begins by defining art as a "synthesis of the fantasy and emotion of the subconscious with the realities apprehended by the reason." Looking at poetry as a specific art form, he identifies the two main elements as music and imagination, or incantation and evocation (Kirkconnell 1928: 14-15), which are closely interwoven with one another. The incantation consists of auditory devices such as rhythm and rhyme. In any great poem, these musical devices must be married to the imagination. Imaginative language becomes evocative when figures of speech such as metaphors and similes are used.

Kirkconnell then asks whether there are any barriers to verse translation. This is once again the perennial question of "is translation possible?". Rather than merely concluding whether it is or is not possible, however, Kirkconnell analyses the nature of the obstacles. One obstacle consists in the adaptability of languages to certain types of incantation. For example, English is ill suited to spondaic measures; it is poor in rhymes and hampered by its brevity of expression. The difficulties on the level of evocation are even greater, for one reason because of the vast vocabulary of English. But he adds another reason that speaks less to the technical difficulties of translation than it does to his own personal anxieties as a writer who is at once ambitious and insecure.

To speak a living word, to create a phrase that shall not be a dull echo of one of a million harmonies in a long, rich literary tradition, is a most difficult task. All previous English poets are in the field against you, condemning as feeble all that does not involve an advanced technique and an originality of phrase that grows more and more difficult with the passing of the crowded centuries. (Kirkconnell 1928: 22)

The chief difficulty lies with communicating the poet's experience: "only emotion in the translator can produce a translation that is poetry." However, no two people's experience can be identical, and the translator will necessarily infuse some of his own experience into the poem. Kirkconnell's conclusion is that given the necessary conditions, translation of verse is possible, even if the work is slightly altered. "The letter killeth, but the spirit maketh alive" (Kirkconnell 1928: 23-24).

The history of the publication of European Elegies is an interesting one. It illustrates the tenacity with which, throughout his career, Kirkconnell would strive to have nearly everything he wrote published, sometimes entirely at his own expense, or with a financial contribution from himself or later on his university. Initially undertaken for therapeutic reasons, or as a personal memorial to his deceased young wife, Kirkconnell gradually realized that the collection of poems might appeal to others 
especially since many of the poems had not appeared in English before (Kirkconnell 1928: 9). He completed the project in less than a year and submitted the idea to the publishers of his thesis, Allen \& Unwin. In his letter to the publishers, Kirkconnell asked advice: whether or not to include the original poems on opposite pages to the translations. Not surprisingly, the reaction of the publisher was not positive:

We thank you for your letter of April 3 [1926] and enclosures. While we shall be very willing to consider the complete MS. of your "European Book of Elegy" when ready, we very much doubt whether we shall see our way to make a proposal for its publication.

As you ask for our "candid advice," we will say quite frankly that we think you have undertaken too big a task. We do not believe there is any living man so intimately acquainted with forty different European languages, past and present, as to be able to translate poems from those languages. ${ }^{2}$

Not deterred even "in the face of such credulity" (Kirkconnell 1967: 58), Kirkconnell set out to find "guarantors" for his translations, authorities in different linguistic fields who could certify that his translations were valid. Among those consulted were scholars at Oxford, Columbia and Harvard Universities. The response, in Kirkconnell's words, was a "universal chorus of approval" (Kirkconnell 1967: 58).

Kirkconnell appears to have attempted to find a publisher using Curtis Brown Ltd, an "international publishing bureau". A year after his devastating response from Allen and Unwin, Kirkconnell received a letter from this firm advising him that J.M. Dent had decided not to undertake publication of his book, but that Curtis Brown would continue to look for a publisher if Kirkconnell were still willing to contribute towards the cost of production (Letter of 22 June 1927, Kirkconnell collection).

The volume was finally published in 1928 by an Ottawa firm, Graphic Publishers. The poems appear in English translation only, and are accompanied by the preface and introduction examined above, along with biographical notes on the original poets.

Kirkconnell kept correspondence with the scholars who were asked to vouch for the quality of the translation. After publication, he seems to have sent copies of the book to a number of people as well, and also kept their correspondence. In addition, the file contains a fair number of press clippings. On the whole, the reactions from quite different quarters are quite positive, although they do not constitute nearly as unanimous as chorus of approval as Kirkconnell later claimed.

On receiving the published volume, Professor Raymond Weeks of Columbia University, who had been asked to comment on translations from Romance languages, wrote:

your Elegies makes an even finer impression than I had foreseen [...] I have gone over these translations with care, and marvel at your skill and range of expression, as well as at your wide scholarship. (Letter of 9 November 1928, Kirkconnell collection)

Professor Neville Forbes of Oxford University, solicited for his knowledge of Slavonic languages, replied with some reservations about the actual translations:

[...] I hold very pronounced views on the rendering of rhymed poems in any Slavonic language into rhymed English verse. Briefly, I consider it is virtually impossible [...] Considered as "free adaptations of the originals" they seem to me more than "adequate," to use your own words. The emotion certainly is there; as regards meaning, you have unavoidably had to depart a good deal from that of the original, especially, it 
seems to me, in the translations from Pushkin and Lermontov. One phrase in Mickiewicz's Storm I frankly do not like [...]. (Letter of 20 September 1926, Kirkconnell collection)

A letter from the President of the Finnish Authors' Association, dated 15 November 1926, refers to Kirkconnell's translations as "interesting renderings" and says that there is no question about his "complete competence". He goes on to point out a few "inadequacies" that are unavoidable in the translation of poetry and mentions specifically one poem in which the rhythm is heavier than in the original. On the other hand, he says, several other poems are "more expressive and living" than the originals. The most striking point in this letter is the gratitude of the writer who, speaking "in the name of Finnish poetry," thanks Kirkconnell for having brought to the attention of an English-speaking public the poetry of Finland, which had remained unknown except for the Kalevala. These two themes, namely that some of the poems are better than their originals (although would the Finnish reader be in a position to judge?) and, secondly, the appreciation to Kirkconnell for his function as promoter of minority literatures, remained constant throughout Kirkconnell's lifetime, and beyond.

W. G. Howard, professor of Germanic Languages and Literatures at Harvard, finds the translation "freer" than he would have wished. He considers it "rationalistic," less "sensuous" or "passionate" than the original, and some expressions even "far-fetched" (Letter of 6 November 1926, Kirkconnell collection).

The most negative assessment in the file is a document that has the appearance of an evaluation done for a publisher as it is unsigned and not on any letterhead. The presumed reviewer says that if the translations were to be considered on their intrinsic poetic merit,

the writer shows himself a humble follower of the romantic tradition, to which he adds nothing, though the poems are frequently felicitous enough [...] it feels to me rather like a man playing the piano with gloves on. [...] a wise publisher, if a publisher who took it would be wise, would leave out the originals, or only print the Slavonic ones, which no one can read. (Undated, Kirkconnell collection)

Another criticism relates to Kirkconnell's choice of poems to be translated. A handwritten note from a professor at the University of Sofia draws attention to the fact that the Bulgarian poems Kirkconnell has selected do not deserve to be translated. This kind of error in judgment is once again underlined some years later when Kirkconnell proposed to write about two Hungarian poets for an issue of the Hungarian Quarterly. The reply from the editor indicates that the two poets in question are not very good poets (Letter of 19 July 1939, Kirkconnell collection).

Newspaper coverage of the publication was enthusiastic. An article in the Windsor, Ontario Border Cities Star, by Gillis Purcell, praises European Elegies as a "masterpiece of poetic translation". The Ottawa Evening Journal, 29 September 1928, devotes a rather long piece to the translations and theoretical ideas of Kirkconnell. In an article entitled "Philological Phenomenon" published on 8 December 1928, the Winnipeg Evening Tribune says: "metrically, linguistically, emotionally, intellectually, and artistically, the manuscript is an achievement and a phenomenon". The Daily Province, published in Vancouver, and the Edmonton Journal, both carry the same article as the Winnipeg paper, but with the byline of a Prof. or Dr. W. T. Allison. 
Thus the chorus was one of less than consistent approval, although the prodigious feats of Kirkconnell usually did meet with admiration. Kirkconnell, of course, was one of his own best promoters. A document in his files summarizes critical opinions on European Elegies: a list of excerpts from the letters quoted above are set out, carefully edited to weed out the slightest trace of negative opinion. In his memoirs, as well, Kirkconnell takes care to include the best of reactions to his work, among which is the following comment from the then secretary of the Swedish Academy's Nobel Prize Committee on Literature (did Kirkconnell hope to win a Nobel prize?):

I have to thank you for a most remarkable book, unique, I think, in its mastery of so many languages, and perhaps unique too-in its widespread and intense feeling for the emotional utterance of mankind. (Kirkconnell 1967: 59)

It was said of Kirkconnell's translations that they were good as long as the originals were not present for comparison purposes. So that readers of this article may judge for themselves, a small sample of his translations, with their originals, are reproduced below: one stanza of "Chanson d'automne" by Verlaine, translated as "Autumn Dirge" (Kirkconnell 1928: 43), and one stanza of "L'Horloge” by Baudelaire, translated as “The Clock” (Kirkconnell 1928: 72).

\author{
Autumn Dirge \\ Autumn begins \\ With violins \\ Of lament, \\ Wounding my breast \\ With dull, oppressed \\ Discontent.
}

\author{
Chanson d'automne \\ Les sanglots longs \\ Des violons \\ De l'automne \\ Blessent mon cœur \\ D'une langueur \\ Monotone.
}

\section{The Clock}

Clock! dull, dread, passionless divinity,

Whose finger writes "Remember" with a threat, In thy pale heart are quivering sorrows set

Like arrows that in mortal quarries lie.

\section{L'Horloge}

Horloge! dieu sinistre, effrayant, impassible,

Dont le doigt nous menace et nous dit: "Souviens-toi»

Les vibrantes Douleurs dans ton cœur plein d'effroi

Se planteront bientôt comme dans une cible.

\section{Other Translations}

Following the success of European Elegies, Kirkconnell envisioned a "colossal volume of Occidental Poetry" (Kirkconnell 1967: 60). He worked on this for a while and eventually obtained a contract from the publisher Louis Carrier for a more scaled down, yet no less ambitious, project: Kirkconnell was to complete twenty-four 200page volumes of translations from European poetry over the next twelve years.

To commemorate the millennial year of the Icelandic parliament in 1930, Kirkconnell began with the translation of Icelandic poetry, to be published under the title A North American Book of Icelandic Verse. The Icelandic volume appeared, but Louis Carrier went bankrupt in 1930. By this time, Kirkconnell had already gone on 
to complete a Magyar anthology. With the help of the editor of a Canadian Hungarian weekly, Kirkconnell was able to publish this collection as The Magyar Muse (1933). A subsequent translation of the Hungarian epic, The Death of King Buda, was published in 1936, this time with the help of Hungarian collaborators who worked with him on a preliminary prose draft and a Hungarian professor of English at the University of Budapest, who checked his final version line for line against the original (Kirkconnell 1967: 63).

While Kirkconnell continued work on the translation of Hungarian verse, he began producing the third volume in the series, a collection of Polish poetry, which appeared in 1936 as A Golden Treasury of Polish Lyrics. Later, to commemorate the centennial of the death of the Polish poet Mickiewicz, in 1955, Kirkconnell undertook the translation of the epic poem Pan Tadeusz, for which a prose rendering had previously been prepared by George Rapall Noyes of the University of California. Kirkconnell was unable to complete the entire translation and by the time he resumed the work in 1958, Noyes was dead. He was given considerable assistance at that time, including that of a six-man "fly-speck reading panel" to check his translation against the original Polish. It was finally published in 1962, with its finest reception, according to Kirkconnell in his memoirs, in the Times Literary Supplement in London (Kirkconnell 1967: 66).

Kirkconnell's most massive undertaking in translation was verse translation from Ukrainian. He produced the 500-page volume The Ukrainian Poets, 1189-1962 and The Poetical Works of Taras Shevchenko, in collaboration with a Ukrainian Canadian, Dr. C. H. Andrusyshen. In this project, he at last had a collaborator who was a master of the original language and literature (Kirkconnell 1967: 69). Over the years, Kirkconnell also translated substantial amounts of verse from Nordic languages such as Icelandic, Norwegian, and Swedish, and several other languages, including Latin, Italian and French. In all, he estimated that he had published some twenty volumes of translated verse, totalling nearly 4000 pages (Kirkconnell 1967: 55). At the time of writing his memoirs, he had an additional 1000 pages "sleeping in his files," many of which appeared posthumously in the nearly 800-page volume Hungarian Helicon (1985).

Like many practitioners of the art of translation, Kirkconnell reflected on his work as a translator. As early as European Elegies, as we have seen, he expressed his views on the challenges of translating verse, and this was to continue throughout his career.

Kirkconnell was not unaware of theories of translation, and in his memoirs remarks that every age has its "fashions" in translation. He draws on Alexander Tytler's 1790 Essay on the Principles of Translation to criticize what he considered to be the excesses of Ezra Pound in his translations from foreign languages (Kirkconnell 1967: 70-71).

Kirkconnell contributed to a 1970 issue of Meta along with Jeannine Bélanger (Sister Marie-Joséfa). Kirkconnell and Bélanger were preparing a bilingual translation of the Psalter. Bélanger, who was working on a French translation from Hebrew, Greek and Latin, had asked Kirkconnell to contribute an English verse translation, to be printed facing the French version. Kirkconnell's article, entitled "Translating the Psalter. The Problem of Metre," is followed by an article by Bélanger entitled “Traduction du Psautier. La Strophique des psaumes" (Kirkconnell 1970; Bélanger 1970). 
In a well researched study of the intricacies of Hebrew verse, Kirkconnell proposes a set of principles governing its translation. One of these provides for a rhymed translation of the unrhymed Hebrew, on the grounds that most English hymns are rhymed (Kirkconnell 1970: 15). This is consistent with Kirkconnell's approach to poetry translation throughout his career. In the example he gives of the translation of Psalm 27, 1, Kirkconnell includes successive versions from the Greek Septuagint, the Book of Common Prayer, and several others. Among the English versions, Kirkconnell's alone is rhymed and, despite his principles, perhaps among the least effective.

In a statement written at age 78 for the Prologue of Hungarian Helicon, a compendium of his Hungarian verse translation published posthumously in 1985, Kirkconnell articulates some of the fundamental preoccupations of literary translators: faithfulness to both the form and meaning of the original; the need to adapt to the literary norms of the target culture; and the tensions that result from the struggle to deal with competing objectives.

My aim in translation has been to pursue two conflicting ideals: (a) to come as close as possible to the meaning and metre of the original, and (b) to produce English verse that is acceptable (as English) in prosody and idiom. It is the tension between these ideals that creates whatever merit (or demerit) my translations may have. (Kirkconnell 1985: $\mathrm{x})$

\section{Other Works by Watson Kirkconnell}

Although Kirkconnell considered verse translation "one of the major activities of [his] life" (Kirkconnell 1967: 55), he devoted considerable energies to a wide range of genres, from poetry to politics. After he completed his volume of translated poetry, Kirkconnell turned his attention to the composition of original verse, The Tide of Life (1930), a kind of translation in fact, which by his own admission was a less than successful attempt to express in the English language the exotic metres of Latin, Greek, Sanskrit, Old Icelandic and Old Irish (Kirkconnell 1967: 42).

Kirkconnell poured his literary energies into a book-length original poem, The Eternal Quest (1934). He later went on to less serious work, authoring Chaucerianstyle tales set in Manitoba. He even published, under a pseudonym, limericks based on Manitoba and Saskatchewan place names, which appeared in daily newspapers in Winnipeg and Regina.

Later in life, following a serious heart attack, Kirkconnell published a series of poems under the title "The Coronary Muse" and a more important volume of poems on historic Canadian themes, Centennial Tales (1965), which utilized a range of different poetic forms.

Although elected to the Royal Society of Canada in 1936 in recognition of The Eternal Quest and his volume of yarns called The Flying Bull and Other Tales, Kirkconnell's does not stand out among Canada's great poets. J. R. C. Perkin, friend, colleague and biographer of Kirkconnell, admits:

it is unlikely that he will be remembered chiefly as an original poet. [...] He was well aware that he was no longer representative of the general patterns of Canadian poetry, although he argues, probably with some justification, that free verse had become too 
free and that more recognition of the place of rhythm and rhyme was necessary if poetry was again to become a form of literature respected and used by more than a handful of poets and critics. (Perkin 1986: 54-55)

Kirkconnell himself remained unapologetic for his adherence to traditional prosody:

my awareness of the whole contemporary field has left me unrepentant in the orthodoxy of my original poetry. [...] My decision, however, has been to follow my own bent and write narrative poetry and occasional satire. Damned if I would kowtow to the high priests of avant-garde dogma, who deny any merit to poets who will not fit their bed of Procrustes! (Kirkconnell 1967: 53)

Kirkconnell devoted considerable time and effort to the study of Milton, producing three works, The Celestial Cycle, That Invincible Samson and Awake the Courteous Echo, not unrelated to translation. In these works of literary scholarship, Kirkconnell translates the "analogues" or models that had influenced Milton in his composition of famous works such as Paradise Lost, for example. In translating these works from their original Latin, Greek, Italian and so on, Kirkconnell contributes to Milton scholarship by enabling readers less versed in foreign languages to examine the sources of the Milton's works. This is an example of translation at the service of literary scholarship.

Kirkconnell worked in a number of other areas, such as history, with a particular interest in the history of the university, his region, and the church. He gave countless presentations and addresses, many of which were published or reprinted in some form or another. One area related to his work as a translator of the multi-ethnic literatures of this country, and which may have had an impact on his position within Canadian letters, was politics.

\section{Watson Kirkconnell and Politics}

From the time that he returned from Europe and took up his post in Winnipeg, Kirkconnell developed close ties with organizations within the ethnic communities. Among the people he frequented were those of Icelandic, Ukrainian, Polish and Hungarian origins. He admired their cultural richness and served these communities by translating their work and writing about their literary achievements. In addition, he defended their rights and advocated harmonious relations among the various groups. As an example of his political activism, Kirkconnell initiated a protest against the Nazi take-over of Poland, and in 1940 drafted a letter, the signatories of which were eminent Canadian intellectuals.

Kirkconnell became virulently anti-Communist. In fact, as he points out in his autobiography, it was Communist onslaughts on the well-loved Canadian communities that he had frequented (Hungarian, Polish, Ukrainian, for example) that had turned him into a "vocal critic of the left" (Kirkconnell 1967: 276). He wrote a booklength study of Communism in Canada and Russia, called Seven Pillars of Freedom (1944), which was the subject of a debate in the Canadian Parliament.

Going back as far as the 1930s, during the war, and in the post-war years especially, Watson Kirkconnell followed events in the Soviet Union carefully. He conducted serious research on Soviet affairs and kept many files on questions such as legislation, anti-religious measures, education, wages and prices. He also followed the 
activities of Canadian communist individuals, organizations, and publications, and there are indications in his papers that he provided the RCMP with information and advice on certain matters.

As a result of Kirkconnell's anti-communist stance, there were frequent attacks on him in left-wing publications such as the Canadian Tribune. He was attacked in the Moscow newspaper Trud in 1944 as a "protector of Ukrainian Fascists in Canada" ("McMaster Professor 'Führer' of Fascists Here, Says Red Paper," Montreal Gazette, 2 November 1944). Closer to home, he was the subject of abuse in the Steelworker and Miner, published in Sydney, Nova Scotia, which lambasted him on a weekly basis in articles with headlines such as "Falsifier Kirkconnell" (11 December 1948) and "Pedagogic Prostitution" (24 December 1948).

\section{The "Third Canadian Muse"}

Associated with work as a translator was Watson Kirkconnell's "discovery" of ethnic literatures in Canada. He was an avid reader of the foreign language press in Canada and became familiar with the work of minority writers in this way. From 1937-1965, he reviewed ethnic literatures (covering the period 1935-1965, at a rate of approximately 70 books a year) in an annual survey of non-English and non-French books, written for the «Letters in Canada» issue of the University of Toronto Quarterly. In 1967, he proposed to University of Toronto Press the publication of a comprehensive survey of Canadian literatures in languages other than French and English. The volume had the support of, and would have received funding from, the Ukrainian Canadian Research Foundation. Kirkconnell proposed the title "The Third Canadian Muse" and would have reproduced the University of Toronto Quarterly reviews. Although University of Toronto press had initially expressed an interest in publishing the proposed volume, it later indicated that other publishing priorities would take precedence. The book was never published.

Kirkconnell's commitment to the "Third Canadian Muse" and his motivation to discover and translate the works of ethnic groups in Canada is not unrelated to his politics. This aspect of his work illustrates his "publicist" attitude, according to Ujszászi, who points out that Kirkconnell's aim in translating poems with a patriotic theme, including the Hungarian National Anthem, or "Himnusz," was to support the new immigrants and make the public aware of their particular situation (Ujszászi 1993: 588-89).

Kirkconnell's promotion of the «New Canadians» is among his most lasting achievements. This contribution is recognized in the Canadian Encyclopedia (Palmer \& Rasporich 1985: 598) and in the Oxford Companion to Canadian Literature (Craig 1997: 597-598). In his autobiography, Kirkconnell himself predicts that this might be the one thing for which he will be remembered:

Taken together, these minor literatures present an unrivalled picture of the human predicament, of lives uprooted from a far country and planted afresh with difficulty in Canadian soil. Perhaps the one thing for which I shall be remembered a century hence will be that single-handed I discovered, surveyed, and recorded in Canada's cultural Registry of Deeds this diverse collectivity of literary achievement, revealing as it does a major factor in the life of the New World. (Kirkconnell 1967: 76-77). 
This is borne out by tributes Kirkconnell received from the ethnic communities themselves. He received from seven Hungarian organizations a letter of congratulations and appreciation, in which the signatories say:

Other Hungarian organizations wish to join in this as they have not forgotten what they owe you for rendering some of our literary works in English, thus building an everlasting bridge between Canadian readers and the Magyar soul [...] we beg to offer our best wishes and ask you to help us further on in becoming more and more appreciative citizens of our New Homeland. (Letter of 29 September 1934, Kirkconnell collection)

In recognition of his achievements, Kirkconnell received numerous honours and distinctions: honourary degrees from the University of Debrecen, Hungary, and several Canadian universities as well. He received a series of decorations, medals and awards: Knight Commander, Order of the Icelandic Falcon, Knight Officer, Order of Polonia Restituta, Gold Medal of Freedom, Hungarian Freedom Fighters, Silver Laurel, Polish Academic of Literary, Czechoslovak Gold Medal, Shevchenko Medal, and so on.

\section{The Place of Kirkconnell in Canadian letters}

Kirkconnell's work has generally been described in superlative terms: "herculean," "prodigious," "monumental". He was, it appears, a man of ambition and exceptional drive, with the discipline required to work toward the attainment of his objectives. One wonders how he came to have the audacity, or chutzpa, to take on the most challenging form of literary translation-poetry-from so many languages. Different kinds of motivation could be ascribed to his project: in the first place, his personal affinity for the elegiac poems he translated during his months of grief; ultimately, his sense of solidarity and friendship for the different groups of New Canadians he came to know. His political principles, as we have seen, guided him to a large extent, no doubt reinforced by the friendship returned by the ethnic communities he served, which extended from loyalty to outright adoration. Kirkconnell assumed the role of translator as missionary, not uncommon later on among English translators of French Canadian literature, motivated by altruism and yet, to some extent at least, personal ambition.

How is it that a man of such achievements holds so minor a place in Canadian letters? Of particular interest to us in this study is the relative obscurity into which he has fallen in the history of translation in the country. A number of possible explanations are possible.

Perkin's judgment of Kirkconnell as a poet is a telling one, confirmed in a recent conversation in which he suggested that Kirkconnell may have been a better translator than a poet. I would suggest that Kirkconnell might have been better remembered as a translator of poetry had he been more of a poet himself, and that one of the factors that has contributed to his obscurity is the unevenness of quality of his vast body of work. He might have stood out more had he been less firmly rooted in nineteenthcentury traditions. Beyond the issue of the intrinsic quality of Kirkconnell's verse translation, in particular, lies that of the appeal and readability of translated verse in general. His work might have had more of an impact if he had engaged in other forms of translation. 
Kirkconnell's politics, as previously indicated, may have played a role in his isolation from at least a certain segment of the artistic community. There is no doubt that his anti-Communist stance was not entirely out of line for his times: he was not alone in voicing suspicions of left-wing groups, particularly in the postwar years. On the other hand, it may have estranged him from certain quarters of the intellectual, writerly community. He does not seem to have been in touch with Frank Scott and other English translators of the day, for example, who were working strictly from French and who would have fallen at the other end of the political spectrum from him.

Perhaps the most important factor is that Kirkconnell aligned himself with a stratum of Canadian society that remained marginalized at the time. Examining Kirkconnell's work from the perspective of Canadian multiculturalism, his collaborator C. H. Andrusyshen (1975) borrows John Porter's term "vertical mosaic" to point out that the New Canadians whom Kirkconnell served occupied the lower levels of society, as compared with the so-called "charter groups" (Porter 1965: 60), the English and the French. Despite Kirkconnell's efforts to promote awareness of the mentality of the different peoples whose writings he translated and to foster "mutual acquaintanceship between the English Canadians and the newcomers" (Andrusyshen 1975: 33), the impact of these ethnic literatures has not, in Andrusyshen's opinion, had any significant influence (1975: 48).

The fact that Kirkconnell's career peaked at a time when Canadian biculturalism was being affirmed can perhaps explain the fact that he has been overlooked. Kirkconnell himself reports in his memoirs that in 1964-65 he was cited before the Royal Commission on Bilingualism and Biculturalism as a "partisan in a multi-cultural counter-attack" against the assumption that the French and the English were the two founding races (Kirkconnell 1976: 282). He was "distressed" at this accusation, and goes on to show some of his connections to French Canadian culture and society.

It has been the case, however, that discussions of language and translation in Canada have focussed primarily on English and French. The preoccupation with the survival of French language and culture in Québec, and the political urgency in the rest of the country caused by the threat of Québec separation have somewhat overshadowed the concerns and activities of other linguistic groups. Canadian translation scholars, who have developed within Canadian translation schools, themselves a product of official bilingualism, have rarely turned their attention to translations from other languages.

Yet, the linguistic landscape of Canada is by no means confined to the two "official" languages. It is possible that if Watson Kirkconnell were alive today, he might have a higher profile within the translators' community. There is some sign of change in attitudes toward "third" languages, with more appreciation for original writing in languages other than the two official ones, and more translators working from other languages. For three of the past four years, for example, the Literary Translators' Association of Canada has awarded its Glassco prize to translations of poetry written in a language other than French or English, and there has been some pressure to have the Canada Council extend its scope to translations beyond English and French. Canada continues to be a country of immigration, and the practice and study of translation must go beyond bilingualism to take full account of the "undoing of Babel". 


\section{NOTES}

1. The expression "undoing of Babel" is taken from the title of a Festschrift published on the occasion of Watson Kirkconnell's 75th birthday (Perkin 1975). In the essay from which the title is drawn, the author, Douglas Bush, actually makes reference to Watson Kirkconnell as having "nullified the curse of Babel" (Bush 1975: 17; emphasis is mine).

2. This letter, dated 14 April 1926, is part of the file pertaining to European Elegies, housed in the Kirkconnell Room at Acadia University. I wish to thank archivist Patricia Townshend for her generous assistance in making this and other materials available to me.

\section{REFERENCES}

Andrusyshen, C. H. (1975): "Canadian Ethnic Literary and Cultural Perspectives." The Undoing of Babel. Watson Kirkconnell, the Man and his Work (J. R. C. Perkin, ed.), Toronto, McClelland and Stewart, pp. 31-49.

Bélanger, Jeannine (1970): “Traduction du Psautier. La Strophique des Psaumes.” Meta, vol. 151 (mars 1970), pp. 18-25.

Bush, Douglas (1975): "Milton Three Hundred Years After." The Undoing of Babel. Watson Kirkconnell, the Man and his Work (J. R. C. Perkin, ed.), Toronto, McClelland and Stewart, pp. 17-30.

Craig, Terrence (1997): "Watson Kirkconnell." Oxford Companion to Canadian Literature. 2nd ed. Toronto, Oxford University Press, pp. 597-598.

Kirkconnell, Watson (1928): European Elegies: one hundred poems chosen and translated from European literatures in fifty languages. Ottawa, Graphic Publishers.

- (1930a): The Tide of Life and Other Poems. Ottawa, Ariston Publishers.

- (1930b): North American Book of Icelandic Verse. New York, Carrier \& Isles.

- (1933): The Magyar Muse. Winnipeg, Kanadai Magyar Ujsag Press.

- (1934): The Eternal Quest. Winnipeg, Columbia Press.

- (1936a): The Death of King Buda: A Hungarian epic poem by Janos Arany, rendered into English by Watson Kirkconnell in collaboration with Lulu Putnik Payerle. Cleveland (Ohio), Benjamin Franklin Bibliophile Society.

- (1936b): A Golden Treasury of Polish Lyrics. Winnipeg, Polish Press.

- (1940): The Flying Bull and Other Tales. Toronto, University of Oxford Press.

- (1944): Seven Pillars of Freedom. Toronto, Oxford University Press.

- (1952): The Celestial Cycle: the Theme of Paradise Lost in World Literature, with Translations of the Major Analogues. Toronto, University of Toronto Press.

- (1962): Pan Tadeusz. English verse translation from the Polish of Adam Mickiewicz. Toronto: Canadian Polish Congress.

_ (1963): The Ukrainian Poets, 1189-1962. Selected and translated into English verse by C. H. Andrusyshen and Watson Kirkconnell. Toronto, University of Toronto Press for the Ukrainian Canadian Committee.

- (1964a): The Poetical Works of Taras Shevchenko, in collaboration with C. H. Andrusyshen. Toronto, University of Toronto Press for the Ukrainian Canadian Committee.

- (1964b): That Invincible Samson: the theme of Samson Agonistes in world literature, with translations of the major analogues. Toronto, University of Toronto Press.

- (1965): Centennial Tales and Selected Poems. Toronto, University of Toronto Press for Acadia University.

— (1967): A Slice of Canada. Memoirs. Toronto, University of Toronto Press for Acadia University.

— (1970): “Translating the Psalter. The Problem of Metre." Meta, vol. 15-1 (mars 1970), pp. 10-17.

- (1973): Awake the Courteous Echo: the themes and prosody of Comus, Lycidas, and Paradise Regained in world literature, with translations of the major analogues. Toronto, University of Toronto Press.

— (1985): Hungarian Helicon. Calgary, Széchenyi Society, Inc. 
Palmer, Tamara J. \& Beverly J. Rasporich 1985. "Ethnic Literature." Canadian Encyclopedia. Edmonton: Hurtig Publishers Ltd., pp. 595-598.

Perkin, J. R. C., ed. (1975): The Undoing of Babel. Watson Kirkconnell, the Man and his Work, Toronto, McClelland and Stewart.

— (1983). "Watson Kirkconnell's Methodology of Verse Translation." Journal of the Atlantic Provinces Linguistic Association / Revue de l'Association de linguistique des Provinces Atlantiques, 5, pp. 16-32.

- (1986): Morning in his Heart. The Life and Writings of Watson Kirkconnell. Biographical sketch by J. R. C. Perkin. Bibliography by James B. Snelson. Wolfville (N.S.), Lancelot Press. PorTer, John (1965): The Vertical Mosaic. Toronto, University of Toronto Press.

UjszÁszi, Zsuzsanna (1993): “Translation as a Specific Form of Interliterary Reception in Watson Kirkconnell's The Magyar Muse (1933).” Proceedings of the XIIIth FIT World Congress, Brighton. Translation-The Vital Link. London, Institute of Translation and Interpreting. Vol. 1, pp. 586-591.

ZorivchaK, R. P. (1993): “The Most Important Problems of Anglophone Shevchenkiana: Translations, Research Works". Proceedings of the XIIIth FIT World Congress, Brighton. Translation-The Vital Link. London, Institute of Translation and Interpreting. Vol. 1, pp. 573-580. 